\title{
PHILOSOPHY OF PUNISHMENT: NORMATIVE MODELS AND CONSTRUCTION PRINCIPLES OF LEGAL SYSTEMS
}

Assist. Prof. Michat Peno, Ph. D. *

UDK: 343.85 .01

343.8:17.022.2

343.8:141.134

DOI: 10.3935/zpfz.69.3.04

Pregledni znanstveni rad

Primljeno: srpanj 2018.

The paper attempts to examine a philosophy of punishment in the normative perspective and to penetrate the structure of the fundamental premises and theses of retributivism. Punishment concepts are discussed in relation to two contexts and types of expressions formulated in the philosophy of punishment - normative and descriptive. The former are a matter of axiology and normative models, whereas the latter constitute a description of existing systems of criminal responsibility. The considerations are centred on a retributive model. The model of retributivism involves normative premises and consists in seeing these premises not as unconditionally binding directives, but as optimization rules, a kind of prima facie duty. These are mainly the quasi-legal duties of the state considered from the point of view of criminal policy. Retributivism can be seen as a set of norms (rules) for constructing legal system. The core of the paper consists in outlining such a concept. The inspiration for it was provided above all by the ideas of the Polish legal theory, R. Dworkin, $W$. D. Ross and R. Alexy, and modern retributivists.

Key words: principles, structure of retributivism, prima facie obligations, punishment, rules for constructing legal systems

* Michał Peno, Ph. D., Assistant Professor, Faculty of Law and Administration, University of Szczecin, Narutowicza 17A, 70-240 Szczecin, Poland; michal.peno@wpiaus.pl;

ORCID ID: orcid.org/0000-0001-9905-3783 


\section{INITIAL REMARIKS *}

The aim of the considerations is to differentiate two possible approaches to the philosophy of punishment and two types of expressions formulated by the philosophy of punishment. It is a starting point for remarks pertaining to possible normative standards for shaping criminal law, also as determinants of criminal policy. At the same time, an attempt was made to outline the retributive model.

As a concept of punishing, retributivism has several variations. However, there is a certain backbone, that is, a certain set of characteristics shared by all retributive approaches. One might claim that these are the constitutive (constituting) characteristics of retributivism. This means that a given system of criminal responsibility deserves to be called retributive only when it bears the said characteristics. However, if one of these characteristics is missing, the name 'retributivism' does not fit a given system of criminal responsibility (statement of reasons for the punishment).

A question arises as to whether the retributivism is a type (to a given type belong objects with a certain set of features, therefore some objects may better fit the type, others less - it is a matter of degree) or whether there is a logical division (a given object is or is not a designate of a given name). It seems that the first one is correct. Concepts from the field of the philosophy of punishment are typological and not classification-based in genere. In the philosophy of law these are types of view on law and legal institutions. Therefore, one can specify certain characteristics (theses) occurring in all views that are retributivism (or a social defence, a trend in resocialisation - social rehabilitation or deterrence, etc.). A set of these characteristics will form certain patterns or models and be subject to graduation irrespectively of a given model (a given type of views may be retributive to a greater or lesser extent, similarly like one can be a legal positivist to a greater or lesser extent). ${ }^{1}$ These models are discussed in the last part of the considerations.

** I am grateful that I had the opportunity to discuss this article during my stay at the Faculty of Law of the University of Greifswald (Germany).

1 Thus, one can claim that the legislator who wanted to introduce, for instance, a model of a fair punishment either succeeded or failed. Alternatively, regulations are more or less successful (in relation to the normative model - pattern as a benchmark). This type of approach shows a similarity to Lon Fuller's interpretation where fulfilment of its 8 formal postulates regarding law as the condition for considering it successful is regarded as a certain (successful or unsuccessful) social undertaking. The word 'success' or the word 'failure' give a good reflection of smooth nature of philosophical criteria and concepts. Cf. Fuller, L., The Morality of Law: Revised Edition, Yale University Press, New Haven, 1969, pp. 33-37; Murphy, C., Lon Fuller 


\section{NORMATIVE AND DESCRIPTIVE PHILOSOPHY OF PUNISHMENT}

It can be easily seen that the so-called philosophy of punishment (sensu $\left.\operatorname{largo} 0^{2}\right)$ has two aspects. These are the descriptive aspect and the normative aspect. Expressions formulated by the philosophy of law can also be analysed in two contexts, i.e. the normative one and the descriptive one. ${ }^{3}$ The philosophy of law is a part of the theory of law in a broad sense. ${ }^{4}$ Expressions formulated on the grounds of jurisprudence contain both a descriptive and normative element, thus constituting a description of the binding norms and postulates de lege ferenda (pertaining to what the content of the norms should be). These fit in with the general methodological assumptions of contemporary jurisprudence in the light of which the aim of the theory of law is to gain knowledge on law, while at the same time, jurisprudence is part of law and participates in how it is shaped. ${ }^{5}$

The descriptive aspect concerns a description of a process of punishment, and its various dimensions, as a phenomenon occurring in a society ruled by law. This aspect can be called a theory of punishment (that involves scientific scrutiny of the social phenomenon of punishment). In this approach, the theory of punishment, similar to the modernist theory of law, can be penology formulating statements on the social practice of punishing. These are also statements on which justification for punishment, idea of punishing or philosophy

and the Moral Value of the Rule of Law, Law and Philosophy, vol. 24, no. 3, 2005, pp. 239-262.

2 This will be explained further. Speaking briefly, it is about the general scrutiny of criminal law (theoretical, economic, axiological etc.), as opposed to the so-called dogmatic of criminal law (involving an analysis of written or positive law).

3 See: von Wright, G. H., Is and Ought, in: Bulygin, E.; Gardies, J. L.; Niiniluoto, I. (eds.), Man, Law, and Modern Forms of Life, Reidel, Dordrecht, 1985, pp. 263-281; Ross, A., Directives and Norms, Routledge \& Kegan Paul Ltd., London, 1968, pp. 34$52,78 \mathrm{ff}$.

4 Peczenik, A., A Theory of Legal Doctrine, Ratio Juris, vol. 14, no. 1, 2001, pp. 75-105.

5 Peczenik, A., Scientia Juris: Legal Doctrine as Knowledge of Law and as a Source of Law, Springer, Dordrecht, 2005, pp. 14-25; Feteris, E. T., Fundamentals of Legal Argumentation. A Survey of Theories on the Justification of Judicial Decisions, Springer, Dordrecht, 1999, pp. 62-72; Peczenik, A., Non-Positivist Conception of Law, in: Teoria prawa. Filozofia prawa. Wspótczesne prawo i prawoznawstwo, UMK, Toruń, 1998, pp. 225 ff.; Ziembiński, Z., The Methodological Problems of Theory and Philosophy of Law. A Survey, in: Ziembiński, Z. (ed.), Polish Contributions to the Theory and Philosophy of Law, Poznan Studies in the Philosophy of the Sciences and the Humanities, Brill Rodopi, Amsterdam, 1987, pp. 39-74. 
of punishment are approved in a given state, in a given jurisprudence, etc. in a given time. The descriptive philosophy of punishment would hence formulate expressions pertaining to a given philosophical (particularly axiological) view on criminal law (e.g. in state $\mathrm{P}$ during time $\mathrm{T}$ a retributive justification for punishment is approved). In this context, it could also describe the actual process of holding someone criminally liable or the direction of criminal policy. In contrast to the normative philosophy of punishment, it gives no recommendations but instead either describes the punishing process or constructs a common theory of punishment, which is a penology free from evaluation. Even if one was to consider such a description to be a model, it does not allow a duty to be derived from it (there is no transition from 'is' to 'should', while in practice, it cannot be stated that since someone or something acts in manner $\mathrm{S}$, then one should act in manner $\mathrm{S}$ ).

In the normative aspect, the philosophy of punishment formulates postulates, recommendations and directives regarding what punishment ought to be. This approach can be called a philosophy of punishment per se in terms of methods, aims and its approach to research object. ${ }^{6}$ The objective of normative philosophy of punishment is hence to formulate recommendations, primarily, to assess criminal law and the concept of punishment. The assessment is made from the perspective of various criteria; however, it is above all an assessment according to the criterion of validity, justice or morality of punishment. Thus, the philosophy of law can be defined as an axiology of punishment. Naturally, other criteria can be applied, such as praxeology, effectiveness of punishment, etc. The normative philosophy of punishment formulates a concept of punishment - it is not a description of a given theory of punishment, but a set of assessments and postulates on punishment. For instance, from a descriptive point of view, one would say that punishment is a kind of revenge, or a just retribution (in terms of social functions and roles in a society). Normatively it can be claimed that punishment ought to be a retribution (then there are at least two possibilities: punishment is a retribution or it is not a retribution in the light of a given system of criminal law). The law does not always work as it would appear from the normative concept of legal institutions. ${ }^{7}$

It is worth to note that normative considerations of this sort play a specific role in criminal policy - they constitute the basic framework or assumptions

6 Cf. Aleksander, A., Philosophy of Criminal Law, in: Coleman, J.; Shapiro, S. J. (eds.), The Oxford Handbook of Jurisprudence and Philosophy of Law (Oxford Handbooks), Oxford University Press, Oxford, 2011, pp. 815-867.

7 Chiao, V., Two Conceptions of the Criminal Law, in: Flanders, C.; Hoskins, Z. (eds.), The New Philosophy of Criminal Law, Rowman and Littlefield, New York, 2016, pp. 20-36. 
of criminal policy. This is because criminal policy covers patterns for shaping criminal responsibility and other mechanisms for fighting crime (being targeted at the effectiveness of law at the same time).

By nature, a normative perspective refers to an assessment. The notion of the assessment including its semiotic analysis and role played in the philosophy of law requires a separate discussion. However, an assessment is undoubtedly the basis for formulating recommendations and directives, and consequently, a specific concept of punishment. ${ }^{8}$

One of the aims of the study is to analyse a chosen normative concept of punishing as a certain normative project. Due to the relative clarity of assumptions, the analysis will be made on the example of a retributivism. It is important to stress that the retributivism is used as an example. Therefore, further remarks shall contain assessment of the retributive approach to punishment. One should bear in mind, however, that the choice of retributivism is a result of this trend being assessed as a deserving promotion or at least defence. The retributive philosophy of punishment may be discussed in a descriptive manner - it is then a description of a model of justification for punishment referring to justice defined in various ways.

In the descriptive aspect, the retributivism constitutes a certain attempt to characterise the ways of justifying punishment from the point of view of a certain philosophical and legal position. Hence, it is a certain theory of punishment, a description of a just punishment (in the type of "Everyone who commits evil, that is, an offence, is to be held responsible and punished proportionally to the weight of the evil done", "the guilty person is punished", etc.). ${ }^{9}$ On the other hand, in the normative aspect, retributivism formulates certain directives regarding when the offender should be punished, and when the community or the state should not apply a criminal reaction. Retributivism formulates certain recommendations regarding punishment. Perceived in such a way, it constitutes a normative concept (or model) of punishment. Normatively understood retributivism could be analysed as a concept that includes a set of rules for the construction of a legal system in the field of criminal law, and the duties imposed by that concept on the legislator. As a result of the acceptance that such

8 Cf. von. Wright, G. H., Norm and action. A logical enquiry, Routledge \& Kegan Paul, London, 1963, pp. 6-16.

9 Morris, H., Persons and Punishment, The Monist, no. 52, 1968, pp. 475-501; Tunick, M., Punishment. Theory and Practice, University of California Press, Berkeley-Los Angeles-Oxford, 1992, pp. 69 ff.; Lucas, J. R., Responsibility, Oxford University Press, Oxford, 2004, pp. 86 ff. 
a concept is of a typological nature, it will be necessary to reconstruct a certain minimum - a normative skeleton of retributivism, allowing for recognising a given concept as retributive and implications resulting from the adoption of this concept (considered from the perspective of the legislator).

On this background we can see that normativity may refer to rules that determine (a) the manner in which punishment is shaped as a certain institution or (b) for justifying punishment. In the latter case, this pertains to normative conditions fulfilment of which determines whether punishment is justified or not (for instance, punishment should meet conditions a - c, if it is to be justified). The difference between the first and the second approach is as follows. The analysis of the degree to which the first type of principles are implemented pertains to considering a given system of criminal responsibility to be retributive (or fitting to this or another approach to punishment - be it utilitarian, communicative or mixed). They answer the question which conditions must be met so that a given system of criminal responsibility is considered retributive (or another that serves for us as a point of reference). In turn, principles of the second kind concern the possibility of justifying punishment in general or in an adopted or declared model, or in any model (i.e. justification of punishment in a given time, given state, given legal system). Hence, they answer the question on which conditions should be met in order for punishment to be considered justified.

\section{NORMATIVE PHILOSOPHY OF PUNISHMENT AND RULES FOR THE CONSTRUCTION OF THE LEGAL SYSTEM}

Let us take a closer look at rules that determine the model (models) of criminal responsibility (punishment) and their relations with criminal policy. These models can be considered as some meta-rules (meta-norms) that are addressed to a state or a legislature, which is for those who are responsible for shaping a system of criminal law. The normative concept of punishment formulates recommendations that can be recognised as certain principles or rules that construct a criminal justice system, in a given country. They will be certain rules for the construction of the legal system concerning this section of reality which concerns criminal law. These will be a kind of meta-rules because the legislator feels bound by them while shaping criminal policy, especially in the process of creating law (but also in the aspect of applying and interpreting the law). The nature of these rules is disputable. They are meta-rules, since they determine the content of lower-level rules - regular legal norms created pursuant to the positivistic concept of sources of law. They are as if principles, yet 
they do not belong to the legal system. ${ }^{10}$ Meta-rules are not a part of the legal system in the sense that these rules are not a source of law. But the legislator is feeling to be bound by these rules or principles. The State or the legislator is ready to embody these meta-rules only because a chosen normative model is morally, politically, ideologically etc. accepted or demanded. Nonetheless, it is not bound by these meta-rules like for instance by the constitution or an act of law. In this sense, it can be said that they are binding only due to axiological reasons and not formal ones. When observing transformations in Central Europe, it is sometimes difficult to determine which values are the legislator's driving force - however, it is certain that he is driven by some rationality. If he is a rational entity (the assumption of rationality being a necessary idealisation), his choices, in essence, should be consistent. The same consistency is the cause of being bound by the previously chosen direction. Therefore, if the choice was a just retribution, the legislator will feel bound by the principle of guilt and proportionality of punishment to the said guilt. These are not just regular norms included in the Penal Code or principles of law as norms distinguished for some reason (of major importance, more significant than others), but principles that organise the legal system and the criminal law system (as if of meta- or pre-legal character). However, it seems that it is still law (in a broad sense).

What is a character of norms, rules or principles creating a given model of punishment, at the level of rules for constructing the legal system? The chosen model of punishment is not manifested directly in the legal texts, including the constitution; however, it may govern the lower-tier legal rules in the sense that every new lower-rank rule will be consistent with it. It is enough for the legislator to be bound by such a meta-rule for it to be recognised as legally binding (although this will be of specific validity, resulting from its formal effectiveness). It is worth noting that the said value of justice will not only be decoded or reconstructed from the legal text at the time of interpretation, but will directly determine the content of legal norms. Retributivism can be analysed in a similar way. Moreover, this philosophical concept will set some quasi-legal duties addressed to the legislator.

It should be emphasised once again that the meta-rules discussed here are legally binding in a specific way; in any case it is not a typical positivist validity of the norm (that is, based on its establishment by the competent body of the state, the so-called origin test), but rather validity through the sense of the legislator (especially understood as the actual entity creating the law) that these

10 Peno, M.; Jaśkiewicz, J., Rule of Law as the Construction Principle of the Legal System, in: Belov, M. (ed.), Rule of Law at the Beginning of the Twenty-First Century, Eleven International Publishing, Hague, Netherlands, 2018, pp. 21-33. 
rules are (legally) binding on him. In addition, this validity is affected by institutional support - conviction of the courts, the science of law (legal doctrine) etc., that these rules are binding in the creation, as well as the application and interpretation of the law.

The rules (a set of rules) for constructing legal systems are norms related to the course of the law-making process and directed to the legislator, and in this case - also norms which govern how to organise the application of law (and as a result, the normative aspects of the functioning of public administration). The rules constructing the legal system specify how to make laws in a valid way, i.e. when the act making a law is effective as well as when the act applying law is valid. These rules can be directed to the institutional legislator (formally as a subject with law-making competency under a certain convention) and to the factual (sociological) legislator who, as a result of some convention, has the factual power to influence the content of effective legal norms. ${ }^{11}$

A traditional, legal-positivist point of view would define the rules constructing the legal system as the legislator's (sovereign's) orders that are addressed to the legislator himself (autonomous rules) and organise the law-making process and the application of law. From the perspective of legal realism, these rules would be in fact some kind of directives of law policy focused on effectiveness in a rational and instrumental sense.

\section{NORMATIVE RETRIBUTIVE CONCEPT AND RULES FOR THE CONSTRUCTION OF THE LEGAL SYSTEM}

One can easily notice that the functions and roles of these rules can be multiplied. By necessity, the scope had to be limited to their general characteristics. It seems that the normative approach to the concepts of justifying punishment can be considered on several levels. Philosophers per se have created complex concepts of justifying punishment. In fact, these concepts are a set of standards, recommendations, principles, and each one of them works as a kind of a normative model of a punishment (or a normative model of a given system of criminal law). The philosophy of law knows three models: utilitarian, mixed or retributive. ${ }^{12}$

11 See: Czepita, S., Reguły konstrukcji systemu prawnego a prawotwórstwom [Rules of Construction of a Legal System and the Law-Making Process], Ruch Prawniczy, Ekonomiczny i Socjologiczny, vol. LVI, no. 4, 1994, pp. 31-38; Peno, M., Jaśkiewicz, J., op. cit. (fn. 10), pp. 21-25.

12 Cf. Lucas, J. R., op. cit. (fn. 9), pp. 280-287. 
Further discussion shall be dedicated to retributivism. However, it is only a choice of an example for illustrating normative aspects of the philosophy of punishment.

One can imagine various ways of shaping the notion of the retributivism. This is a type of model of punishment. As it will be seen further, a given system of criminal law may be more or less retributive. However, this model should be used as consistent as possible by the legislature. This aim is not difficult to achieve, because models by nature are relatively flexible. ${ }^{13}$

The retributive concept is a type, and some characteristics are decisive for belonging to it. Because retributivism (as a model) is a type of justification for punishment, one of the three basic ones that are known in the legal philosophy (there are also utilitarianism and the so-called mixed theories), the question arises about a certain minimum set of features that a normative retributive concept must possess, therefore a certain skeleton of the retributive concept of punishment. Generally speaking, retributivism recommends the application of punishment as retribution proportional to the burden of evil committed by the perpetrator. ${ }^{14}$ This is the basic principle of retributivism. Of course, retributivism has many more variants.

It can be said that three main approaches (within a broader model of retributivism) can be currently distinguished in connection to retributivism. First - the pure theory of repayment, second - the expressive theory, and third - the fairness theory (social balance theory). ${ }^{15}$ The first theory refers to a narrowly understood category of retributive justice that demands a punishment proportional to the wrong that was done (to the offence). The perpetrator of an offence deserves to be punished, which constitutes repayment, if not vengeance. The offender ought to be punished because he or she deserves it. ${ }^{16}$ Philosophy of

13 As we will see a retributive model is governed by a special principle (here called retribution principle) from which one can deduce less important rules or directives. There are also different interpretations of this principle (and rules), as a result there are different models of retributivism.

14 Honderich, T., Punishment. The Supposed Justifications Revisited, Pluto Press, London, 2005, pp. 36 ff.; Anderson, S., The Enforcement Approach to Coercion, Journal of Ethics and Social Philosophy, no. 1, 2010, pp. 1-31.

15 Ryberg, J., The Ethics of Proportionate Punishment. A Critical Investigation, Kluwer Academic Publishers, Dordrecht, 2004, pp. 43-50.

16 Nozick, R., Philosophical Explanations, Harvard University Press, Cambridge, 1981, pp. 377 ff.; Zaibert, L., Punishment and Revenge, Law and Philosophy, vol. 25, no. 1, 2006, pp. $81 \mathrm{ff}$. 
criminal law includes a dialogical element in the second theory, namely, the perpetrator deserves to be punished, but, on top of that, punishment should be exacted because of the message it carries, a condemnation of the act, and the demand of society, including the victim, for the wrong to be righted. The perpetrator deserves punishment as well as condemnation, and he or she ought to repent (the so-called secular repentance). ${ }^{17}$ The third theory stems from the idea of social contract and social balance and asserts that the perpetrator ought to be punished not only because he or she deserves it, but also because a certain balance of benefits and burdens must be restored. The perpetrator enjoys more freedoms and fewer burdens than his or her fellow citizens who chose not to commit an offence and remain honest members of society. Balance ought to be restored, which is possible by means of criminal punishment. ${ }^{18}$

All these approaches share a common core that is a link with vengeance. Vengeance is retaliation for a harm done. ${ }^{19}$ It involves, as a result, the claim that society or the state has an obligation to repay (retaliate) for a wrong (an offence) manifested in punishment ${ }^{20}$, which can additionally carry a message to the responsible moral subject - the perpetrator - or a means to restore a fair balance of burdens and benefits - ordo iuris. They do not exhaust all possible ways of justifying punishment, of course. The fundamentalist character of this claim doesn't allow for a formulation of a conditional justification - that is one that would include conditionality of the duty to repay. It is so even though dogmatic institutions of criminal law themselves allow for limitations in connection to the obligation to punish, and so the impossibility of justifying punishment in certain circumstances (e.g. instances of a political and criminal protection of offenders who testify in criminal cases). ${ }^{21}$ Also, the goal of criminal proceedings in most jurisdictions is not only to punish the perpetrator, but also to ensure that an innocent person is not punished (which is an act of balancing the interest of the innocent with the obligation to respond to a crime - sometimes the latter

17 Feinberg, J., The Expressive Function of Punishment, Princeton University Press, Princeton, 1970, p. 98; Primoratz, I., Punishment as Language, Philosophy, vol. 64, no. 248, 1989, p. 199.

18 Cottingham, J. G., Varieties of Retribution, Philosophical Quarterly, vol. 29, 1979, pp. 238 ff.; Duff, R. A., Trials \& Punishment, Cambridge University Press, Cambridge, 1986, p. 289; Morris, H., op. cit. (fn. 9), pp. 475 ff.

19 Cragg, W., The Practice of Punishment: Towards a Theory of Restorative Justice, Routledge, London \& New York, 2016, p. 12.

20 It can be called "retributive principle". See supra.

21 Cf. Husak, D., Overcriminalization. The Limits of the Criminal Law, Oxford University Press, New York, 2008. 
must give way before the former, which reflects the way criminal proceedings or the system of criminal justice is shaped per se). ${ }^{22}$

What are then the rules that determine the model of (normative) retributivism? J. R. Lucas indicates the following characteristics of retributivism: firstly, punishment should be a retribution for the evil done, secondly, punishment should be a kind of suffering or ailment, thirdly, it should be conditioned on guilt, and fourthly, mercy should give way to strict and strong reaction to evil (an offence). Likewise, J. R. Lucas characterizes other approaches to punishment, but that is not the only characteristic present in the literature. ${ }^{23}$

Summing up, the principle of retributivism primarily imposes the duties of: a) punishment of (only) the perpetrator of the offense (thus not the innocent individual), b) punishment only for the sake of justice - punishment as retribution, c) punishment proportional to the burden of evil committed. As a result, another duty arises, that is, the duty of d) penalizing only such acts whose moral disapproval can be demonstrated in the manner adopted in a given social system. These rules determine the criminal justice system in a given country and the way it is shaped. Punishment as retribution seems to be justified if and only if conditions (a) - (d) are met..$^{24}$

Let us notice that this sort of characteristics of retributivism, i.e. rules that determine how the retributive model of criminal responsibility should operate, can be considered a set of conditions for using the word 'retributivism' properly. This means that the legal system that consciously punishes the innocent or does so in a manner that is disproportionate to the burden of one's guilt, etc. does not deserve to be called retributive (depending on the intensity of utilitarian features could be for instance called a mixed one). Consequently, from the perspective of punishment justification, punishment could not be justified in a retributive manner. Thus, it would not be a just retribution. Therefore, for an advocate of a just punishment, it would be a means for implementing social objectives at the expense of a man, and hence a reaction to an offence of immoral nature (as proved by, e.g. Herbert Morris who criticized the social rehabilitation

22 Cf. Merryman, J. H., The Civil Law Tradition. An Introduction to the Legal Systems of Western Europe and Latin America, Stanford University Press, Stanford, 1969, pp. 132-148; Duff, R. A., Answering for Crime. Responsibility and Liability in the Criminal Law, Hart Publishing, Oxford-Portland, 2007, pp. 195 ff.

23 Lucas, J. R., op. cit. (fn. 9), pp. 92-93.

24 Bennett, Ch., The Varieties of retributive experience, Philosophical Quarterly, vol. 52, no. 207, 2002, pp. 145-163; de Greiff, P., Deliberative Democracy and Punishment, Buffalo Criminal Law Review, vol. 5, no. 2, 2002, pp. 373-403. 
model). ${ }^{25}$ Another matter is determining the moment from which punishment would not be justifiable in any way (poena iniustissima non est poena).

The rules for the construction of a legal system reflect a pattern of shaping the broadly understood criminal law in a given country; it is rooted in a specific legal culture and social order. The meta-rules defining retributivism can be reduced to four main points. For instance, retributivism claims that perpetrators ought to be punished because of the demands of justice - because they deserve to be punished. Moreover, the state ought to protect the innocent and punish those who are guilty (nullum crimen sine poena). One more is a proportionality of the punishment to the guilt (severity of the offence) and is also an optimization norm (directive), a certain principle of punishment. It is worth to note that due to the typological nature of concepts such as retributivism (utilitarianism, etc.) and the soft nature of meta-rules that determine a given system of punishment, these duties that arise from the said meta-rules cannot be considered in zero-one terms, as binding (for the legislator) or non-binding. This is because these are not binding in the same way regular rules do, but as principles (to make a reference to Ronald Dworkin). ${ }^{26}$

It seems that these meta-rules are optimizations norm (that norm can be fulfilled only to some extent). It doesn't mean that the state may punish the innocent in the interest of society (i.e. there is no norm that prohibits punishing the innocent as a means to a goal or, all the more so, a duty to do so), but that it ought to do everything in its power not to punish the innocent, but to promoting the nullum crimen sine poena principle. That goal cannot so much be achieved or not achieved as achieved gradually. It seems, however, that they will be prima facie duties. In other words, a normative framework of punishment has a prima facie character.

Presented characteristic is just a proposal that should be developed and modified. However, these four elements, taken together, characterize retributivism as a general duty to administer justice in line with the retributive model of punishment. The guilty-principle is fundamental, however, as it defines retributivism in a positive way. They outline retributivism's core in relation to

25 Morris, H., op. cit. (fn. 9), pp. 480 ff.; Wootton, B., Crime and the Criminal Law: Reflections of a Magistrate and Social Scientist, Stevens \& Sons, London, 1981, pp. 31-64; Lucas, J. R., op. cit. (fn. 9), pp. 87-123, 280-286; Kaufman, A. S., The Reform Theory of Punishment, Ethics, vol. 71, no. 1, 1960, pp. 49-53; Arrigo, B. A., Social Justice/ Criminal Justice. The Maturation of Critical Theory in Law, Crime, and Deviance, West/ Wadstworth, Scarborough, 1998, pp. 1-14.

26 See: Dworkin, R., Taking Right Seriously, Harvard University Press, Harvard-Cambridge, 1980. 
utilitarianism or penal abolitionism. The claim that there is a norm promoting retributive reaction, instead of norm prohibiting criminal punishment as repayment for a wrong (it can be called the merci-principle) nor a norm requiring that instrumental results be obtained through punishment, is in opposition to the program of penal utilitarianism, which sees punishment as a means to certain social or personal ends (as prevention, resocialization etc.). ${ }^{27}$ It is also a conclusion incompatible with the abolitionist or minimalist approach, which sees punishment as conditionally permitted or prohibited for moral reasons. ${ }^{28}$ They do not provide an answer to the question about the reason for punishing, however - yet if we eliminate the utilitarian value, justice considerations stand out from among other possibilities. Supplementing the acceptance of punishment as repayment for an offence are three farther duties, which are however optimization norms, meaning that they don't have a fundamental character. Rather, they must be performed in the highest possible degree. Violating them is not permissible as a matter of principle, however.

Retributivists declare that it is a duty of society or the state to repay for a wrong (offence) by means of punishment. In principle, they also oppose punishing the innocent (but this is rather a matter of facts). ${ }^{29}$ Retributivists believe that disregarding offence and guilt manifests unjustified objectivization of the offender. The symmetrical opposite of the right to be punished is the right not to be punished. It seems that it is impossible to avoid punishing the innocent, at least in the real world. This is not, however, a matter of normativity, but rather the adjustment of normativity to facts. No normative model would work if it does not correspond to actual social expectations and needs. As such, which can be seen even in Hans Kelsen's works, each normative system must have a certain minimum social effectiveness. ${ }^{30}$ For that reason, the normative model of retributivism (punishment) will account for the fact that sometimes those who are punished are innocent or that offenders are not punished for various reasons. As a result, there are two possible solutions. Abandoning some norms

27 Kaufman, A. S., op. cit. (fn. 25), pp. 49-53.

28 Christie, N., Conflicts as Property, British Journal of Criminology, vol. 17, no. 1, 1977, pp. 1-15; Peno, M., Punishing (Non-)Citizens, Archiwum Filozofii Prawa i Filozofii Społecznej [Archives for Philosophy of Law and Social Philosophy], vol. 2, no. 13, 2016, pp. 28-38.

29 Cf. Tebbit, M., Philosophy of Law, Routledge, London-New York, 2005, pp. 155-230.

30 See: Kelsen, H., Law, State and Justice in the Pure Theory of Law, The Yale Law Journal, vol. 57, No. 3, 1948, pp. 377-390. Cf. Vinx, L., Hans Kelsen's Pure Theory of Law: Legality and Legitimacy, Oxford University Press, Oxford, 2007; Clark, R. S., Hans Kelsen's Pure Theory of Law, Journal of Legal Education, vol. 22, no. 2, 1969, pp. 170-196. 
as inadequate and modifying the model or considering these norms - rules that determine the normative model of punishment to be a prima facie rule (i.e. more or less effective in accordance to the scheme).

As it is seen two analogies can be employed to explain how the idea of model retributivism works. The first analogy uses a concept of legal principle. The second one refers to an idea of prima facie obligations. ${ }^{31}$ The vision of prima facie duty depends on interpretation. Prima facie duty is only an apparent but not a real duty; or a real duty that can be outweighed by more stringent considerations but continues to survive even when outweighed. The second interpretation seems to be better suited to the retributivism idea of punishment. There is a real obligation or duty to punish, but there is not the obligation that can be either fulfilled or not. It can be assumed that the society or the state has the obligation to do as much as it's possible to repay for an evil and promoting an idea of justice.

Rules for the construction of a legal system as rules that determine the manner of shaping criminal law show some similarities to the principles of law in Ronald Dworkin's approach, except for the fact that they are applied primarily to the creation of law, and only as a consequence, to the application and interpretation of law (it is worth remembering though that Dworkin developed the issue of principles on the basis of the legal system in which the courts create law). ${ }^{32}$ This means that the legislator will fulfil the duties resulting from the retributive concept in so far as they are not permanently in conflict with other values. The fact that some act is a moral evil or harm done by someone (even being a crime) does not mean that it will be punished fairly. The legislator may decide that a given act should remain in the area of morality rather than crim-

31 W. D. Ross introduces the concept of prima facie duty. He suggests the name "prima facie duty" or "conditional duty" as a "as a brief way of referring to the characteristic (quite distinct from that of being a duty proper) which an act has, in virtue of being of a certain kind (e.g. the keeping of a promise), of being an act which would be a duty proper if it were not at the same time of another kind which is morally significant." Farther on we read: "We have to distinguish from the characteristic of being our duty that of tending to be our duty. Any act that we do contains various elements in virtue of which it falls under various categories. In virtue of being the breaking of a promise, for instance, it tends to be wrong; in virtue of being an instance of relieving distress it tends to be right". Ross, W. D., Right and the Good, Clarendon Press, Oxford, 1930, p. 19.

32 Dworkin, R., op. cit. (fn. 26), pp. 22 ff; Dworkin, R., The Model of Rules, in: Hughes, G. (ed.), Law, Reason, and Justice, University of London Press, New-York-London, 1969, pp. $14 \mathrm{ff}$. The application and interpretation of law take into account the values coded in the legal text by the legislator in the law-making process. 
inal law or provide for non-punishment due to the objectives of the criminal policy (non-conviction of key witnesses). There may be finally a case in which, for preventive or social reasons, the legislator decides to punish for acts that are not evil or, in certain cases, allow punishment exceeding the moral burden of the act. However, we should in principle claim to be dealing with a retributive model of punishment, and that punishment will have a retributive justification.

The rules for the construction of the legal system also show some similarity to the program standards (policies) and are sometimes reflected in acts of constitutional rank (e.g. regarding criminal liability or the rule of law). They order to do everything possible in the given circumstances to achieve certain goals. From a formal view, there are obviously limitations to this liquidity of content of norms or rules specifying criminal responsibility. These are prima facie, but only to some extent. Hence, there is a framework to this elasticity. This is an interesting issue, which comes as quite obvious to lawyers. It seems for example that the principle of nullum crimen, nulla poena sine lege is not such an optimizational norm, because of the principle of the rule of law, which prohibits punishment for acts that were not offenses at the time when they were committed. However, it is worth remembering that in the event of a collision with other values (human dignity), the punishment of offenses that did not constitute offenses at the time of their commitment can be justified in the light of positive law (there have been precedents, for instance Nuremberg). One can hardly miss the link between the outline of criminal justice presented above and Robert Alexy's understanding of principles. According to Robert Alexy, principles are optimization requirements. They can be fulfilled only to some extent. ${ }^{33}$ This is also how a principle of retributivism can be formulated. It would assert that the state ought to realize justice in the highest possible degree. It seems that this approach is not only compatible with the essence of retributivism but also remains in opposition to penal utilitarianism.

The principle of retributivism outlined above, and the duties covered by this principle, are prima facie in nature. ${ }^{34}$ This means that the legislator should only strive to fulfil all recommendations resulting from the retributivism. Of course, they will only strive for this if they want to implement the formula of retributive justice in the criminal law, which should be expressed in legal texts or legislative materials, if the legal system recognizes them as sources of law. From a normative point of view, the duties arising for the legislator from the

33 See: Alexy, R., On the Structure of Legal Principles, Ratio Juris, vol. 13, no. 3, 2000, pp. 294-304.

34 Cf. Hart, H. L. A., The Ascription of Responsibility and Rights, in: Flew A. (ed.), Essays on Logic and Language, Oxford University Press, Oxford, 1951, pp. 145-166. 
adoption of a normative concept of retributivism in criminal law may be considered prima facie according to W. D. Ross. On this level, the principle of fair retribution is certainly relative (e.g. the legislator always, for important reasons, can provide for a more or less severe punishment than it results from the nature of the punishable offense). Retributivism presupposes (assumes), however, that it is not immoral to return evil (punishment) for evil (crime). The supporters of penal abolitionism (Nils Christie et al.) are of the opposite opinion. ${ }^{35}$ This assumption is absolute and is the ethical basis of retributivism (along with the idea of retributive justice).

Taking retributivism as a certain normative model leads us to following conclusions. The legislator should do everything possible to achieve objectives arising from the recognized (adopted) model of the criminal law system (or a concrete philosophy of punishment). The implementation of the chosen model is a kind of prima facie obligation (of a political or quasi-legal nature), if it is possible in a given socio-legal situation or context. Moreover, directives (standards, rules or principles) resulting from the adopted model of the penal system are prima facie by nature.

Importantly, it doesn't mean that one would have to develop a mixed theory, which would on the one hand include the teleological aspect of punishment and on the other hand the duty to repay. Every penal theory constitutes a model, which, as an idealization, enables the study or analysis of punishment. It doesn't reflect reality, but may respond to its challenges. Taking the axiological standpoint, one may think of W. D. Ross' theory of prima facie duties. In W. D. Ross' ethical system rightness is identified with moral duty. A right act is an act that still ought to be performed (morally binding) ${ }^{36}$ Besides characterizing prima facie duty, Ross proposes a list of certain fundamental prima facie duties involving the duties of reparation (of a wrong) or the duties of justice which are characteristic for retributivism. ${ }^{37}$ Ross says that one principle can always be abandoned for another, in the sense that some departures from the rule are permitted. Ross's theory, from the point of view of retributivism, is only a kind of guideline. More-

35 Christie, N., Crime control as Drama, Journal of Law and Society, vol. 13 no. 1, 1986, pp. 1- 8.

36 Ross, W. D., op. cit. (fn. 31), pp. 3, 91-93.

37 These are: 1) the duties of fidelity, 2) the duties of reparation (of a wrong), 3) the duties of gratitude (to others for services done by them to one), 3) the duties of justice, 4) the duties of beneficence, 5) the duties of self-improvement, 6) the duty of non-maleficence. Ross, W. D., op. cit. (fn. 31), pp. 21-22, 27. Cf. Johnson, O. A., Rightness and Goodness. A Study in Contemporary Ethical Theory, The Martinus Nijhoff, Hague, 1969, p. 9. 
over, the chapter of Ross's The Right and the Good dealing with the relationship between the duties of the state and the rights of the citizens in the context of punishment is well-known. According to Ross the state has the duty to protect the innocent. It ought to do everything in its power in order to prevent citizens' rights from being violated, but those who do not respect others' right to life, freedom or possession lose (or limit) their own right to these goods. Therefore, the state doesn't have a prima facie obligation to protect offenders. The conclusions Ross draws are incompatible with retributivism - also, the fluid character of the principle of justice, as it were (its prima facie character), seems to contradict modern retributivist thought inspired by Kant's ethics. Ross states that society's interest may be great enough to justify the right to punish an innocent individual, so as to prevent the destruction of the whole nation. ${ }^{38}$ The essence of retributivism is its clear opposition to sacrificing an individual for the common good as principle of criminal responsibility. Otherwise retributivism would become a supplement to utilitarianism reduced to the requirement to consider guilt a premise of responsibility and moral condemnation of crimes, while accepting the possibility to make exceptions for the sake of special considerations, such as public interest.

\section{CONCLUSIONS}

In conclusion, it must be emphasised that the philosophy of punishment creates normative models of a criminal law. These models have specific names (i.e. retributivism) and each of them can be understood as a set of directives addressed to the legislator. These directives (rules, principles) are for constructing legal system (including the system of criminal law). By its normative character they are morally, ideologically, or quasi-legally binding for the legislator. These directives may be interpreted also as prima facie obligations, just like the rules that make up these normative models. But in fact, these rules are binding and are at the heart of the legal system. As for practical consequences, we may consider de lege ferenda postulate to put main rules for constructing said model directly into the constitution or acts that regulate criminal policy. If needed, such regulations must be simply created and enacted. It is a responsibility of political decision-makers. It would be the implementation of the legal philosophy to practice. There are many examples why penal codes failed in this area. ${ }^{39}$

38 Ross, W. D., op. cit. (fn. 31), pp. 56-64.

39 Cf. Ristroph, A., Two Conditions of Legitimate Punishment, in: Flanders, Ch.; Hoskins, Z. (ed.) The New Philosophy of Criminal Law, Rowman and Littlefield, New York 2016, pp. 76-92. 
It should be emphasised that the legislator is free to choose the concept of punishment, but the choice made (e.g. related to the reform of criminal law) means the obligation to pursue a specific criminal policy. ${ }^{40}$ If the legislator adopts a given vision of criminal justice, they should be consistent and the degree of implementation of the adopted assumptions will be subject to assessment and will affect the possibility of justifying punishment in a given social system and legal order. A change in criminal policy will require an explicit change in the formula of justice. The ideal would be if the legislator directly in the legal text (e.g. in the criminal legislation) defined the adopted principles of criminal policies, tasks of punishment and related to liability punishment values (e.g. by introducing the adopted formula of retributive justice into the legal text).

What, then, does the retributivism demand from the legislator? The retributive character of the outlined concept is manifested by the following characteristics. First - justice remains a value that must be pursued in the highest possible degree. A just repayment is thus the value and the goal that ought to be pursued. Second - the assertion that punishment shouldn't constitute (only) a means to achieving certain goals and shouldn't be inappropriate to the degree of guilt and the severity of the offence.

It is worthwhile to consider such approaches to retributivism which, while modifying the classical, formal and fundamental (and thus contrafactual) idea of justice, remain in acute opposition to the utilitarian programme in criminal law. ${ }^{41}$ The conception outlined here embraces this idea of just punishment.

Retributivism, as a normative concept of punishment, imposes on the legislator some duties of a quasi-legal nature, but also moral ones. It also means the legislator's recognition of a certain hierarchy of values, reflected in legal regulations. These are not absolute duties. However, despite the prima facie character, they are particularly binding on the state, and one can demand their implementation by referring to the principle of a democratic state of law (the rule of law). Citizens can demand stable and consistent criminal policy on this basis. ${ }^{42}$ These categories are blurred, but if the philosophy of criminal law has the ambition to go beyond postulates, it must look for normative concretizations of its concepts.

40 See: Carvalho, H., Liberty and Insecurity in the Criminal Law: Lessons from Thomas Hobbes, Criminal Law and Philosophy, vol. X, no. 11, 2017, pp. 249-271.

41 It seems that retributivism, having undergone various changes, has gradually adopted a mixed form, essentially combining utilitarianism with certain justice-oriented considerations.

42 Cf. Duff, R., A Criminal Law for Citizens, Theoretical Criminology, no. 14, 2010, pp. 293-309; Scalia, A., The Rule of Law as a Law of Rules, University of Chicago Law Review, no. 56, 1989, pp. 1175-1188. 


\section{BIBLIOGRAPHY}

Aleksander, A., Philosophy of Criminal Law, in: Coleman, J.; Shapiro, S. J. (eds.), The Oxford Handbook of Jurisprudence and Philosophy of Law (Oxford Handbooks), Oxford University Press, Oxford, 2011, pp. 815-867

Alexy, R., On the Structure of Legal Principles, Ratio Juris, vol. 13, no. 3, 2000, pp. 267-287, doi: 10.1111/1467-9337.00157

Anderson, S., The Enforcement Approach to Coercion, Journal of Ethics and Social Philosophy, no. 1, 2010, pp. 1-31

Arrigo, B. A., Social Justice/Criminal Justice. The Maturation of Critical Theory in Law, Crime, and Deviance, West/Wadstworth, Scarborough, 1998

Bennett, Ch., The Varieties of retributive experience, Philosophical Quarterly, vol. 52, no. 207, 2002, pp. 145-163, doi: 10.1111/1467-9213.00259

Cane, P., Responsibility in Law and Morality, Hart Publishing, Oxford-Portland 2002 Carvalho, H., Liberty and Insecurity in the Criminal Law: Lessons from Thomas Hobbes, Criminal Law and Philosophy, vol. X, no. 11, 2017, pp. 249-271, doi: 10.1007 / sl1572-015-9369-y

Chiao, V., Two Conceptions of the Criminal Law, in: Flanders, C.; Hoskins, Z. (eds.), The New Philosophy of Criminal Law, Rowman and Littlefield, New York, 2016, pp. $20-36$

Christie, N., Crime control as Drama, Journal of Law and Society, vol. 13 no. 1, 1986, pp. 1-8

Christie, N., Conflicts as Property, British Journal of Criminology, vol. 17, no. 1, 1977, pp. 1-14

Clark, R. S., Hans Kelsen's Pure Theory of Law, Journal of Legal Education, vol. 22, no. 2, 1969, pp. 170-196

Cottingham, J. G., Varieties of Retribution, Philosophical Quarterly, vol. 29, 1979, pp. 238-246, doi: 10.2307/2218820

Cragg, W., The Practice of Punishment: Towards a Theory of Restorative Justice, Routledge, London-New York, 2016

Czepita, S., Reguty konstrukcji systemu prawnego a prawotwórstwo [Rules of Construction of a Legal System and the Law-Making Process], Ruch Prawniczy, Ekonomiczny i Socjologiczny, vol. LVI, no. 4, 1994, pp. 31-38

de Greiff, P., Deliberative Democracy and Punishment, Buffalo Criminal Law Review, vol. 5, no. 2, 2002, pp. 373-403, doi: 10.1525/nclr.2002.5

Duff, R., A Criminal Law for Citizens, Theoretical Criminology, no. 14, 2010, pp. 293-311, doi: 10.1177/1362480610369784 
Duff, R. A., Answering for Crime. Responsibility and Liability in the Criminal Law, Hart Publishing, Oxford-Portland, 2007

Duff, R. A., Trials \& Punishment, Cambridge University Press, Cambridge, 1986

Dworkin, R., Taking Right Seriously, Harvard University Press, Harvard-Cambridge, 1980

Dworkin, R., The Model of Rules, in: Hughes, G. (ed.), Law, Reason, and Justice, University of London Press, New York-London, 1969, pp. 14-24.

Feinberg, J., The Expressive Function of Punishment, Princeton University Press, Princeton, 1970

Feteris, E. T., Fundamentals of Legal Argumentation. A Survey of Theories on the Justification of Judicial Decisions, Springer, Dordrecht, 1999

Fuller, L., The Morality of Law: Revised Edition, Yale University Press, New Haven, 1969

Hart, H. L. A., The Ascription of Responsibility and Rights, in: Antony Flew (ed.), Essays on Logic and Language, Oxford University Press, Oxford, 1951, pp. 171-194

Honderich, T., Punishment. The Supposed Justifications Revisited, Pluto Press, London, 2005

Husak, D., Overcriminalization. The Limits of the Criminal Law, Oxford University Press, New York, 2008

Johnson, O. A., Rightness and Goodness. A Study in Contemporary Ethical Theory, The Martinus Nijhoff, Hague, 1969

Kaufman, A. S., The Reform Theory of Punishment, Ethics, vol. 71, no. 1, 1960, pp. 49-53, doi: 10.1086/291314

Kelsen, H., Law, State and Justice in the Pure Theory of Law, The Yale Law Journal, vol. 57, No. 3, 1948, pp. 370-390

Lucas, J. R., Responsibility, Oxford University Press, Oxford, 2004

Merryman, J. H., The Civil Law Tradition. An Introduction to the Legal Systems of Western Europe and Latin America, Stanford University Press, Stanford, 1969

Morris, H., Persons and Punishment, The Monist, no. 52, 1968, pp. 475-501, doi: 10.5840/monist 196852436

Murphy, C., Lon Fuller and the Moral Value of the Rule of Law, Law and Philosophy, vol. 24, no. 3, 2005, pp. 239-262, doi: 10.1007/s10982-004-7990-3

Nozick, R., Philosophical Explanations, Harvard University Press, Cambridge, 1981

Peczenik, A., Scientia Juris: Legal Doctrine as Knowledge of Law and as a Source of Law, Springer, Dordrecht, 2005

Peczenik, A., A Theory of Legal Doctrine, Ratio Juris, vol. 14, no. 1, 2001, pp. 72 105, doi: 10.1111/raju.2001.14.issue-1 
Peczenik, A., Non-Positivist Conception of Law, in: Teoria prawa. Filozofia prawa. Wspótczesne prawo i prawoznawstwo, UMK, Torun, 1998, pp. 223-248

Peno, M., Punishing (Non-)Citizens, Archiwum Filozofii Prawa i Filozofii Społecznej [Archives for Philosophy of Law and Social Philosophy], vol. 2, no. 13, 2016, pp. 28-38

Peno, M.; Jaśkiewicz, J., Rule of Law as the Construction Principle of the Legal System, in: Belov, M. (ed.), Rule of Law at the Beginning of the Twenty-First Century, Eleven International Publishing, Hague, The Netherlands, 2018, pp. 21-38

Primoratz, I., Punishment as Language, Philosophy, vol. 64, no. 248, 1989, pp. 187-205, doi: 10.1017/s0031819100044478

Ristroph, A., Two Conditions of Legitimate Punishment, in: Flanders, Ch.; Hoskins, Z. (ed.), The New Philosophy of Criminal Law, Rowman and Littlefield, New York, 2016, pp. 76-92

Ross, A., Directives and Norms, Routledge \& Kegan Paul Ltd., London, 1968

Ross, W. D., Right and the Good, Clarendon Press, Oxford, 1930

Ryberg, J., The Ethics of Proportionate Punishment. A Critical Investigation, Kluwer Academic Publishers, Dordrecht, 2004

Scalia, A., The Rule of Law as a Law of Rules, University of Chicago Law Review, no. 56, 1989, pp. 1175-1180

Tebbit, M., Philosophy of Law, Routledge, London-New York, 2005

Tunick, M., Punishment. Theory and Practice, University of California Press, Berkeley-Los Angeles-Oxford, 1992

Vinx, L., Hans Kelsen's Pure Theory of Law: Legality and Legitimacy, Oxford University Press, Oxford 2007

Wootton, B., Crime and the Criminal Law: Reflections of a Magistrate and Social Scientist, Stevens \& Sons, London, 1981

Wright von, G. H., Is and Ought, in: Bulygin, E.; Gardies, J. L.; Niiniluoto, I. (eds.), Man, Law, and Modern Forms of Life, Reidel, Dordrecht, 1985, pp. 263-282

Wright von, G. H., Norm and action. A logical enquiry, Routledge \& Kegan Paul, London, 1963

Zaibert, L., Punishment and Revenge, Law and Philosophy, vol. 25, no. 1, 2006, pp. 81-118, doi: 10.1007/s10982-004-6727-7

Ziembiński, Z., The Methodological Problems of Theory and Philosophy of Law. A Survey, in: Ziembiński, Z. (ed.), Polish Contributions to the Theory and Philosophy of Law, Poznan Studies in the Philosophy of the Sciences and the Humanities, Brill Rodopi, Amsterdam 1987, pp. 39-74 


\section{Sažetak}

Doc. dr. sc. Michał Peno*

\section{FILOZOFIJA KAŽNJAVANJA: NORMATIVNI MODELI I GRADIVNA NAČELA PRAVNIH SUSTAVA}

U radu se pokušava analizirati filozofija kažnjavanja iz normativne perspektive te prodrijeti u strukturu temeljnih premisa i teza retributivizma. O konceptima kažnjavanja raspravlja se sobzirom na dva konteksta i tipa izražavanja koji su izgrađeni u filozofiji kažnjavanja - normativni i deskriptivni. Prvi pripadaju području aksiologije i normativnih modela, dok drugi opisuju postojeće sustave kaznene odgovornosti. Rasprava u radu pritom je usredotočena na retributivni model. Model retributivizma uključuje normativne premise te ih ne smatra bezuvjetno obvezujućim smjernicama nego pravilima optimizacije, na određeni način prima facie obvezom. To su u prvom redu kvazipravne obveze države promatrane sa stajališta kaznene politike. Retributivizam se može shvatiti kao skup normi (pravila) za izgradnju pravnog sustava. Jezgra je rada upravo razrada toga koncepta, pri čеmu su inspiraciju za navedeni pristup dale teze iznesene u poljskoj teoriji prava te djela i ideje R. Dworkina, W. D. Rossa i R. Alexya, kao i modernih retributivista.

Ključne riječi: načela, struktura retributivizma, prima facie obveze, kazna, pravila za izgradnju pravnih sustava

* Dr. sc. Michał Peno, docent, Fakultet prava i javne uprave, Sveučilište u Szczecinu, Narutowicza 17A, 70-240 Szczecin, Poljska; michal.peno@wpiaus.pl;

ORCID ID: orcid.org/0000-0001-9905-3783 